
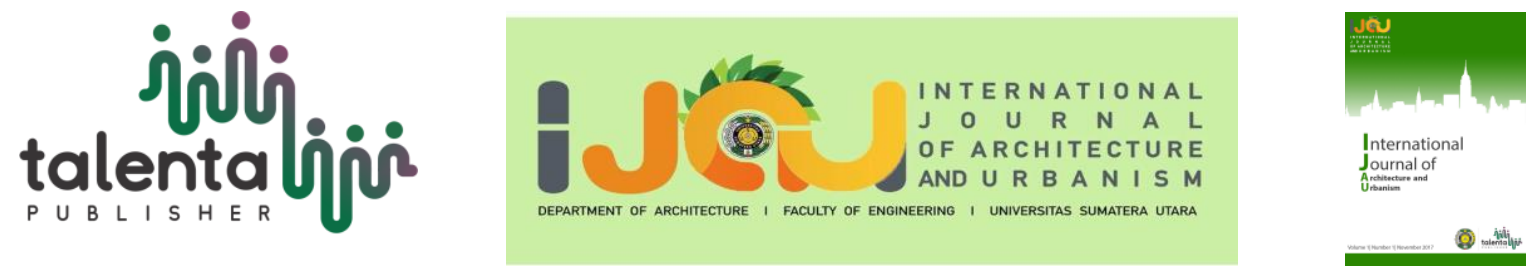

\title{
Behavioral Architecture Approach to Concept of Housing for the Face of Pandemic
}

\author{
Zhilli Izzadati Khairuni ST.,MT ${ }^{1^{*}}$, Ir. Kemala Jeumpa $M T^{1}$ \\ ${ }^{1}$ Department Education building techniques, A state university, williem Iskandar street, Medan City, \\ Indonesia
}

\begin{abstract}
One effect caused by a calamity is the psychological impact on the community. In December 2019 covid-19 viral infected many countries including Indonesia which later changed his status to make cause serious problems because there is no vaccine to prevent transmission of the virus. This condition requires every society to comply with government regulations as quarantine, PSBB, WFH, social distancing. The psychological impact that is often found in society is afraid of panic and other stress. Psychology is closely related to conducting this study will discuss architectural behavior that plays a role in the relationship between people and space. This research as if would explain what occurred in behavior and how your family made the architect can solve this problem by emphasizing psychiatric problems through the application for building design, occupancy of a room. The theory of architecture as a guide in determining objects for the attention that the occupants need through analysis of the type of activity and used before and during the pandemic. This approach asserts the need to understand the behavior and needs of the people living in the house in use. This research activity was carried out with space objects selected based on the similarity of form and design of the average home in Medan City. In activities, the research was conducted with a sample housing path in our name in "Villa Nusa Sempurna" with different types of houses, and various characters users and primary focus will also be on the type of house that is most in demand are in residential. Is a type of type 70 most interested in shape and arrangement with the most commonly found in residential of the town. The result of this research is designed products have been analyzed based on the assessment of behavior so that it can become a new alternative designing safe and comfortable housing for the face of a pandemic.
\end{abstract}

Keyword: Architecture, behavior, house, pandemic.

Received 13 May 2021 | Revised 6 June 2021 | Accepted 8 August 2021

\section{Introduction}

Indonesia facing problems in the growing covid-19 being pandemic. Manufacturing, the industrial sector retail industry, tourism, hospitality, flight, and other with the impact. Economic impact pandemic virus covid-19 derived from more complex, changes give the effect of a great producer

\footnotetext{
*Corresponding author at: Department Education building techniques, A state university, williem Iskandar street, Medan City, Indonesia

E-mail address: zhilli_ft@unimed.ac.id
}

Copyright (c) 2021 Published by Talenta Publisher, 
and consumer, in the material losses caused for businesses in several regions [9]. The people are very much determined by social background, culture, and religion. By the background Indonesians of social activities, culture, religious, and the interests of for the middle to lower, so handling such as the covid-19 PSBB, WFH, social distancing will experience difficulty in implementation by various community social activities in terms of religion, culture, etc [10].

Basically, the environment outside the public sees as a threat to health, while the environment around and in safe houses, while the hospital was the cure to isolate and covid-19 persons exposed to. Quite the contrary the public hall or the environment outside the no guaranteed safe from the spread of the virus [5]. Waning social interaction among others can be felt from activities carried out en masse in the regulation referring to public health minister 20209 number year on guidelines for large-scale social restrictions ( psbb) in order to accelerate the handling covid-19 13 article [6].

Man as a social species is never out of forming their own environment. Of social and human architecture where a building is designed, consciously or unconsciously, affect the behavior patterns of the living human in the architecture and its environment. The architecture was built to meet the needs of the people. And vice versa, from architecture we brought human need just returned [11]. Life has a strategic role in the formation of character and personality as an effort to build the Indonesian individual in his totality, themselves independent, and productive and fulfill the needs of living quarters is basic needs to every single human being, who will continue to exist and develops in accordance with stages or human life cycle [12].

And for the formation of a supposed to some of the things that could not be, standardization because if in terms of the needs of each will have them, plus a distinction of character, to any human being from the house form and culture by Rapoport (1969) [4], At least there are five major aspects that can affect the formation of dwelling among others: Some basic need, Family, Position of women, The need for privacy, Social intercourse.

The inhabitants of the house behavior lived in a good urban area just because, rural areas and in a residential compound having the difference in the perception of building users [8], Housing is one form of a dwelling that links that are strongly with its community [1]. A neat thing to observed is on an estate built en masse by the developer that is generally used the cost efficiency as well as the procurement in the activities of the. This condition led the spending budget that is inefficient by the occupant and alteration of the function are not functionally, to cause the decreasing quality of the house and the environment [2]. The condition of the house on an estate for the same room on every house needs to adapt the owner with their real demand coupled with the condition of impromptu pandemic make the needs of space have increased in the house of the. Also besides, it cannot be denied the state or situation faced by every day different from before the onset of this 
pandemic. Everyone may have had some difficulties but there are administrative difficulty in can be different in each one.

Double workload experienced by adults while I was working in the house that was between work done at a house with homework itself, yes, down to obstacles such as economic hardship due to the project and income. Besides, students who use the method of long-distance learning will not fun for some of us because also restrict interaction directly with others. Adaptation on the current state such as can be had an impact on their mental health in the society such as anxiety excess (anxiety) or stress [3]. The activity of education that have been carried out directly in spatial class replaced by learning online at the house based on circular letter kemdikbud no 4 the year 2020 on the implementation of the education in the hour of emergency coronavirus disease ( covid-19) education and culture ministry of the Republic of Indonesia, 2020 increases the burden of space on a dwelling house [7].

Though completely still at home to exact in the spread of, done preventive measures but some day-to-day activities outside the can are passed. When the exertion or activity requires to outdoors, certainly before entering house some a number of things to do, as: before entering into the and interacting with the family the condition in the state of clean hands, have washed bathroom, clothing and bring and do not touch objects potential animals transmitting the virus. If it felt difficult housing conditions in general in the first room in is a service area beneficiaries and not for washing the hands etc. Research to know who deserves to problems raised during this study, in general, will be outlined to the nucleus problems formulation study, the:

1. The problems faced by the community is facing the condition of pandemics, when my wife was in the behavior of the people as problems activities wfh (work from home), teaching and learning behavior in children school and entertainment activities without out of the house.

2. Limited knowledge of the community in developing businesses in order to maximize their potential during the quarantine. Where the increased availability of space on the occupancy of the houses that now it has not been preparing alternatives in case of pandemics.

In a situation of above, the question research, that can be said is to what extent: "community efforts in preparing the pandemic ahead in occupancy as needed?"

\section{Methods}

Methods used to research this is the method of descriptive qualitative. A method in investigating the status of a people, an object, a set of conditions, a system of thought, or an event. To make a description, a picture in systematic, factual, and accurate about the facts to phenomena is investigated. Research descriptive the problems qualitative studies in society, including about the 
relationship, activities, attitude, and the process of the ongoing and influence of a phenomenon. As for the steps consisting of several kinds of data, namely:

\subsection{Determining the location}

The location of the research how housing in Medan City, because of the housing representing such type-type housing at some point of Medan City. The process will be explained in figure 1.

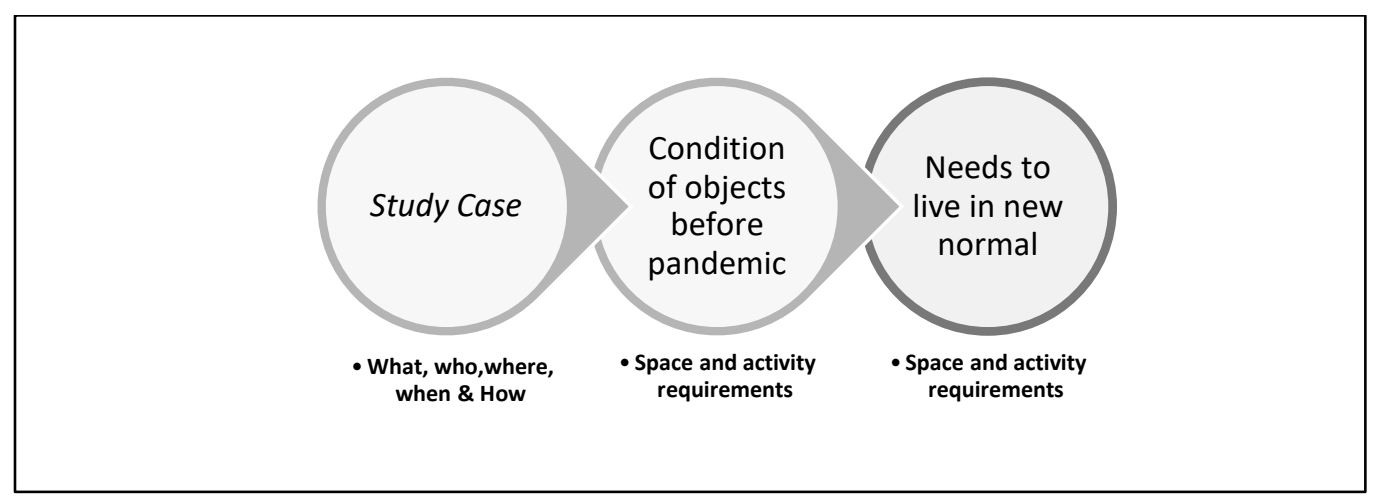

Figure 1. Process in research activities Source: Personal Data

Of location, research is in scope dwelling the lived at housing in Medan City, where this study behavior to users will review the room of a house and the conditioning space and behavior during the pandemic. Object spaces in the research are dwelling houses and activities that happened. Is type 3 dwelling in an area this residence, the housing is on the perfect the villa nusa sempurna. The following are depictions of housing research pictures will be an object (Figure 2).

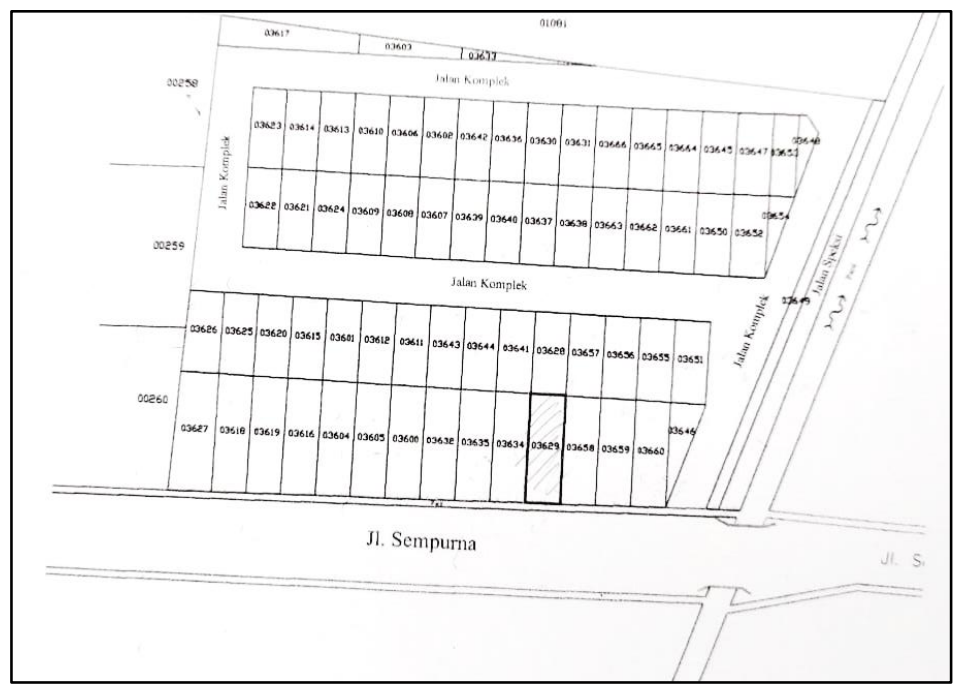

Figure 2. Research locations of housing Source: Developers

\subsection{Determine the literature}

Study literature obtained from several theories architecture and behavior and psychology architecture. To be supported by the law of Indonesia about housing and residential compound 
and the direction of the government to prevent and breaking the chain for the transmission of covid-19. Besides $t$ architecture theory, some comparative studies for consideration and input from architect professionals in making housing in limited land size, with the concept of sustainable and environmentally friendly. A literature study is explained in figure 3 .

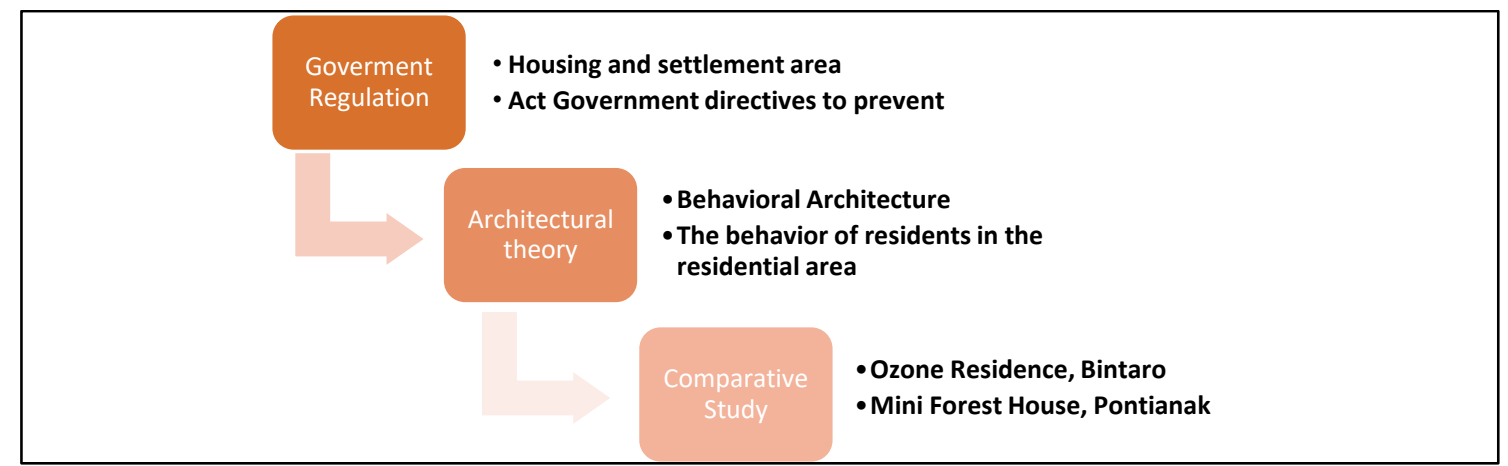

Figure 3. The study supporting library research activities Source: Personal Data

\subsection{The result of research activities}

The results of the analysis from the descriptions for the qualitative criteria will formulate, the model, and the design dwelling houses in dealing with pandemic by approach theory architecture behavior. The result of this research activity is the result of the survey, analysis, and interview of occupants type 70 carried out at random. Where architecture behavior a role in creating the concept of a dwelling appropriated users spend our new normal. The process will be explained in figure 4 .

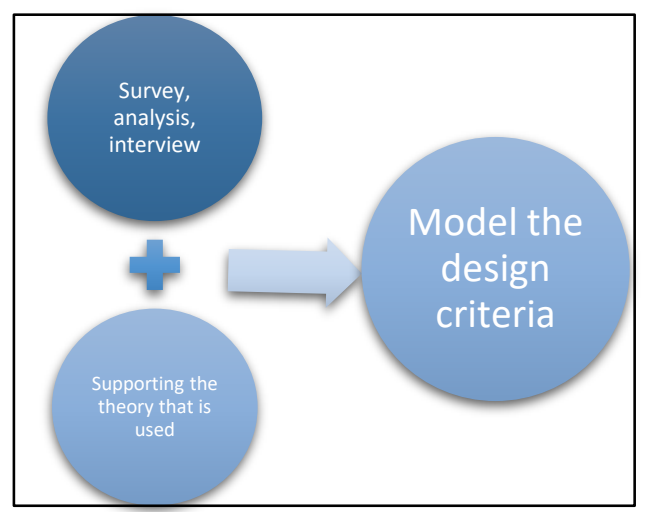

Figure 4. process of producing research Source: Personal Data

\section{$2.4 \quad$ Results}

The study areas are a housing having 60 houses with 3 type different home, in determining the unit would check, data collection and the location to obtain the data-data house of types research object home in the neighborhood, as follows:

1. House is listed and inhabited for the housing. On the data obtained by survey the field 
additional details, with 60 houses 14 houses type 70, 30 houses type 60 and 16 houses type 45

2. 4 of a job classed in categories of civil servants, civil servants, entrepreneurs, and other (workers, cash), etc. Occupants type work on housing areas as the object of this research will determine the activity before and after the pandemic happens.

3. The percentage of the age of the head of the family. The inhabitants of the house know to observe a kind of activities performed in the short-term and long-term impact of the inhabitants of the house. This condition for considering the use of materials so that following users

4. The number of families was back to earn points occupants, what with the 2 families and the more, or equal to the number of family members with 1 family.

5. The number of the house this is done to see if the space bedroom corresponds to the number the inhabitants of the house and what room is required every activity, the inhabitants of the house to the aged and types of activities.

6. The average, children's education as considerations such as those children in the house. activities because the school from home would be different bags child at the primary school level, the primary school first secondary school, junior high school the high school senior high school, and a scholar.

From this, obtained data factors and classifications explained in table 1.

Table 1. Analysis in determining focus research

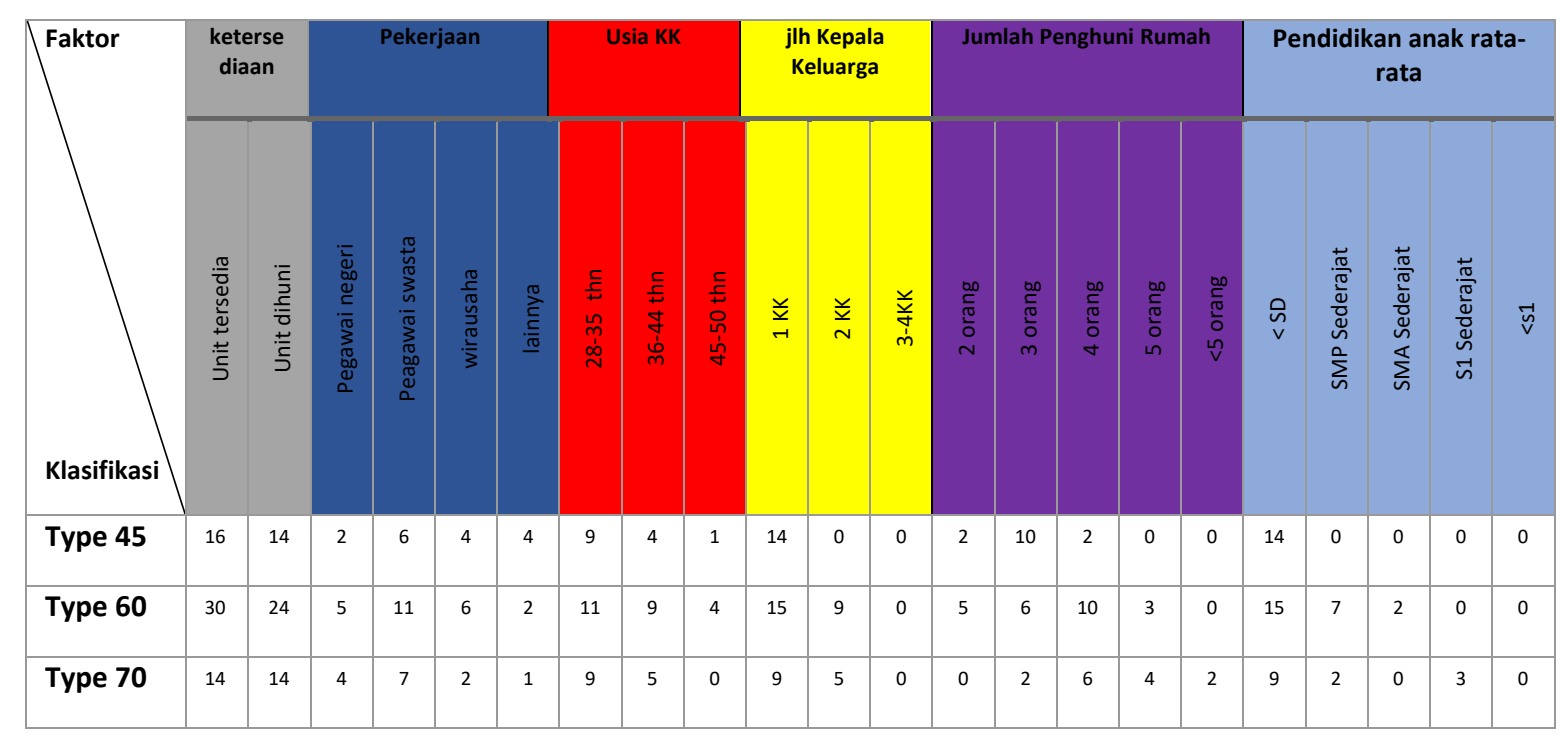

Source: Personal Data

\subsection{The findings of the results of the analysis}

The analysis shows the number of units occupied and for the housing in this is unit type 70, with age families of 28 primary school year, 44 number of head of the family dominated 1 the head man family and the number of people average people in 1 of 4.Unit type 70 is in the front housing facing directly to a big way, so display the show as if this unit not part of the housing, at some 
houses type 70 function illegally into office in addition to function and the other business. So, research will focus on the unit of this type which 70-floor plan having the form of lengthwise with poor circulation. Some displays of this type 70 are explained in terms of function and the house owner. In the figure, 2 the office, used as the delivery of goods so that the front for its used as a parking area and display this house is display scratch on the developer and has not timed of purchase of the increasing fences and canopy in figure 5 .

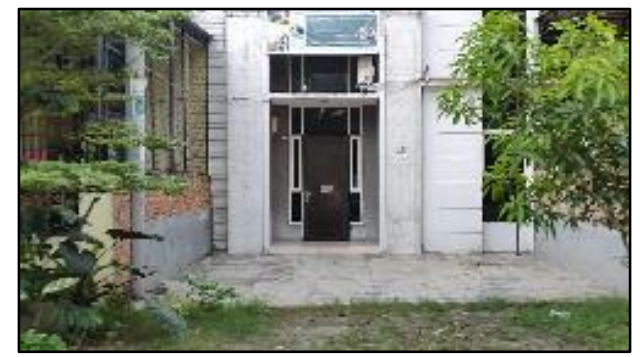

Figure 5. A unit of type 70 which functioned as an office Source: Personal Data

Then unit type used as 70 other functions as a house by the canopy and usage of fences and open land as a park in figure 6.

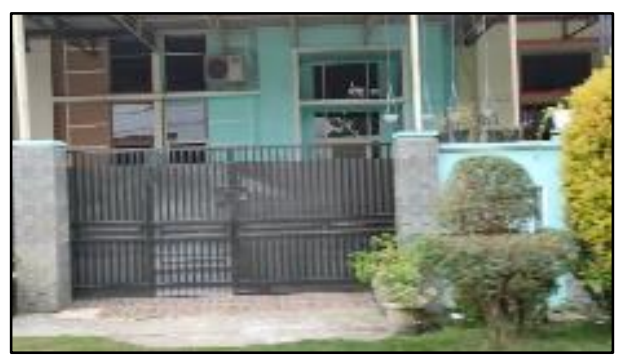

Figure 6. A unit of type 70 after there are more fences and a canopy. Source: Personal Data

A unit of type 70 hereof adding new functions on the front so that an open-air circulation declining and no green land. gardens in front of the house should function at the garage as cars and motorbikes as in figure 7.

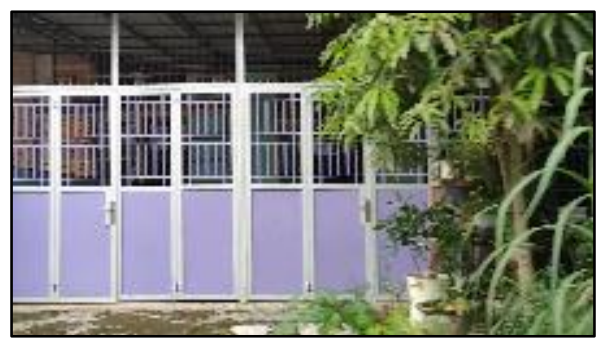

Figure 7. A unit with the addition of the function of Source: Personal Data

Unit type 70 used as a home and offices at this housing area, here as in figure 8. 


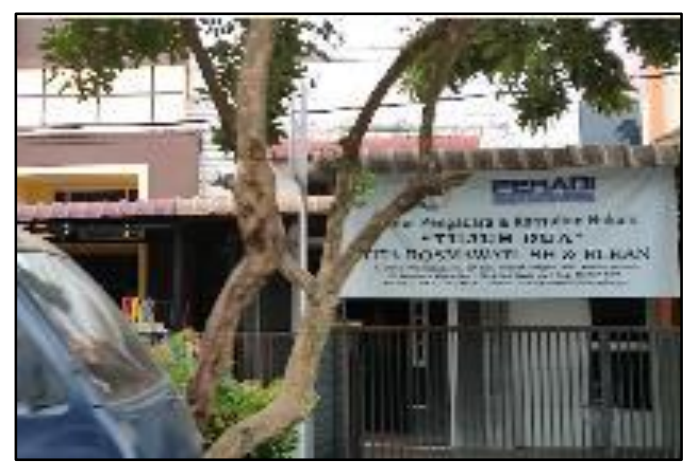

Figure 8. Unit 70 type as the home and office Source: Personal Data

Analysis unit floor-plan type 70 type of 70 with the size of the $6 \times 12 \mathrm{~m}$, having carport, the living room, a dining room, the kitchen, 3 bedrooms, and 1 toilet in their figure 9 .

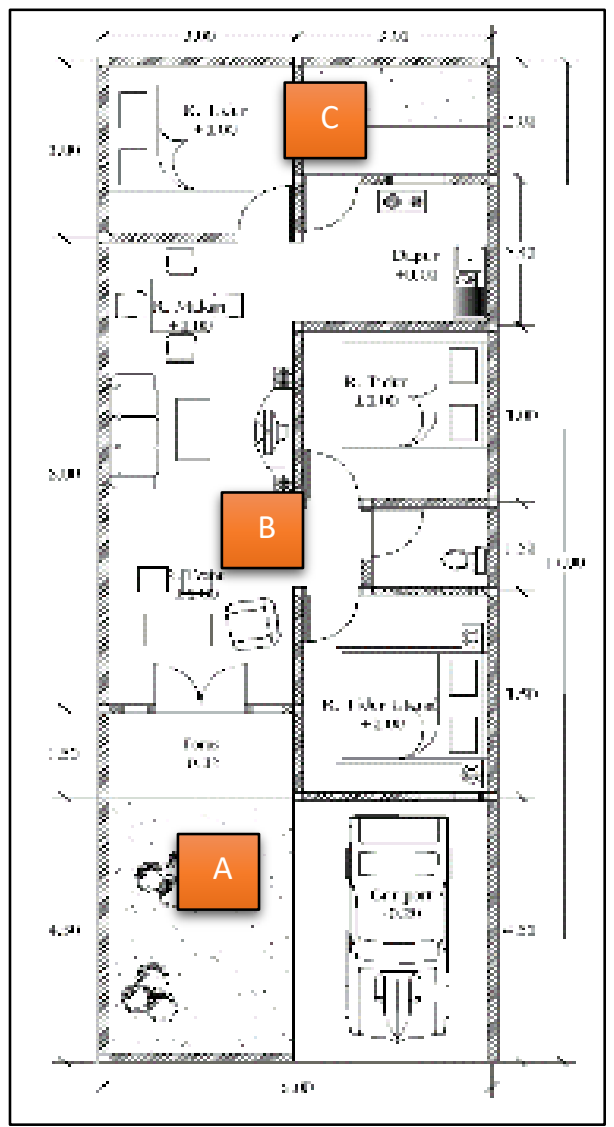

Figure 9. Plans of 70 type Source: Personal Data

The type of information in floor-plain 70 is as follows:

1. Building with the size of the $6 \times 12 \mathrm{~m}$, it has a carport $3 \times 4.5 \mathrm{~m}$, park of size $3 \times 3 \mathrm{~m}$, and a terrace with size $3 \times 1.5 \mathrm{~m}$, on the land and the next the division in the parking area, carport adapted to reflect the needs and our front porch and appetites the owner, give because four idle lands on the front of a house, so the part is designed and built by the owner

2. The principal bedroom with broad $3 \times 3.5 \mathrm{~m}, 2$ bedrooms, and other broad $3 \times 3 \mathrm{~m}$, the 
interesting design is a condition in the room not having circulating air and no vent to light, enclosed in by a kitchenette and bathroom so that space will have artificial illumination morning tonight. And the worse by the absence of this ventilation and the door is opened and there will be an exchange of air. as described in figure 10 .

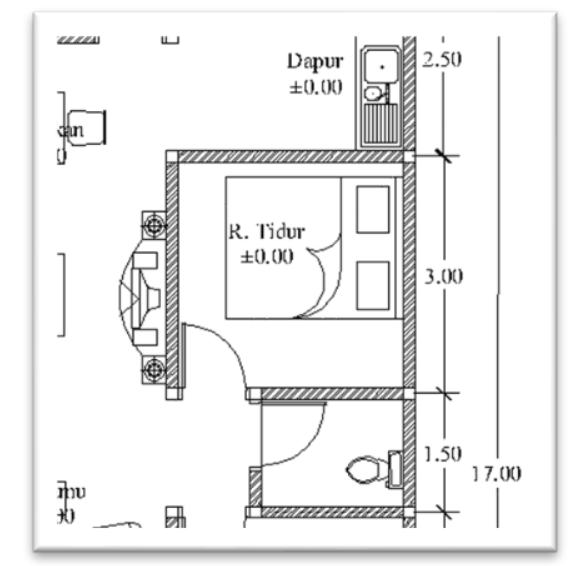

Figure 10.The room a bedroom at type 70 Source: Personal Data

3. The service is at the rear of the house, designed as an open to maximize circulating air, it is just that almost all the closed access is to be an additional room, such as the addition of a bathroom and other, so as to drying clothes done in front of a house in the garden front (figure 11)

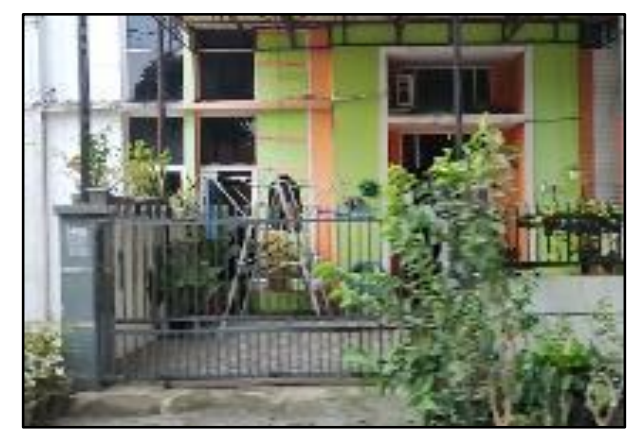

Figure 11.The front of the house as a growth area drying area Source: Personal Data

And research activities are done to changes in activity and conduct where sample research activities carried on the respondent who worked as employees at government agencies and private companies at an object for behavior research before and after the pandemic.

\subsection{Analysis the behavioral changes the inhabitants of the house}

Behavior is as of the inhabitants of the house spaces and the productive activity work (Monday s.d Thursday ) and the does not work ( Saturday and Sunday ), analysis 4 event was held in time. Activities 1 described in the table 2 
Table 2. Space and activities before pandemic

\begin{tabular}{|c|c|c|c|c|c|c|c|c|c|}
\hline \multirow[t]{2}{*}{ Room Name } & \multirow[t]{2}{*}{ Kinds of activities } & \multicolumn{4}{|c|}{ Monday through Friday } & \multicolumn{4}{|c|}{ Saturday to sunday } \\
\hline & & $\begin{array}{l}07.00- \\
09.00\end{array}$ & $\begin{array}{l}10.00- \\
12.00\end{array}$ & $\begin{array}{l}13.00- \\
17.00\end{array}$ & $\begin{array}{l}18.00- \\
21.00\end{array}$ & $\begin{array}{l}07.00- \\
09.00\end{array}$ & $\begin{array}{l}10.00- \\
12.00\end{array}$ & $\begin{array}{l}13.00- \\
17.00\end{array}$ & $\begin{array}{l}18.00- \\
21.00\end{array}$ \\
\hline Terrace & $\begin{array}{l}\text { Sit back relax/ } \\
\text { receive temporary } \\
\text { guests }\end{array}$ & - & - & $\checkmark$ & - & $\checkmark$ & $\checkmark$ & - & $\checkmark$ \\
\hline Living room & receive guests & - & $\checkmark$ & $\checkmark$ & $\checkmark$ & - & $\checkmark$ & - & $\checkmark$ \\
\hline Family room & $\begin{array}{l}\text { Watch tv/family } \\
\text { gathering }\end{array}$ & - & - & $\checkmark$ & $\checkmark$ & $\checkmark$ & $\checkmark$ & $\checkmark$ & $\checkmark$ \\
\hline $\begin{array}{l}\text { Main } \\
\text { bedroom }\end{array}$ & Rest/sleep & - & - & $\checkmark$ & $\checkmark$ & $\checkmark$ & - & $\checkmark$ & $\checkmark$ \\
\hline Bedroom & Rest/sleep & - & - & $\checkmark$ & $\checkmark$ & $\checkmark$ & - & $\checkmark$ & $\checkmark$ \\
\hline Kitchen & $\begin{array}{l}\text { Cooking/washing } \\
\text { dishes }\end{array}$ & $\checkmark$ & - & $\checkmark$ & $\checkmark$ & - & $\checkmark$ & - & $\checkmark$ \\
\hline Service Area & dry in the sun & $\checkmark$ & - & $\checkmark$ & - & $\checkmark$ & - & $\checkmark$ & - \\
\hline
\end{tabular}

Source: Analysis Result

When pandemic and activities psbb imposed happened very drastic shift inactivity, where there is the room does not function as it should and some which the activity of going in almost all the room of a house as you explained in table 3.

Table 3. Space and activities during outbreak, recovery and new normal

\begin{tabular}{|c|c|c|c|c|c|c|c|c|c|}
\hline \multirow[t]{2}{*}{ Room Name } & \multirow[t]{2}{*}{ Kinds of activities } & \multicolumn{4}{|c|}{ Monday through Friday } & \multicolumn{4}{|c|}{ Saturday to sunday } \\
\hline & & $\begin{array}{l}07.00- \\
09.00\end{array}$ & $\begin{array}{l}10.00- \\
12.00\end{array}$ & $\begin{array}{l}13.00- \\
17.00\end{array}$ & $\begin{array}{l}18.00- \\
21.00\end{array}$ & $\begin{array}{l}07.00- \\
09.00\end{array}$ & $\begin{array}{l}10.00- \\
12.00\end{array}$ & $\begin{array}{l}13.00- \\
17.00\end{array}$ & $\begin{array}{l}18.00- \\
21.00\end{array}$ \\
\hline Terrace & $\begin{array}{l}\text { Sit back relax/ } \\
\text { receive temporary } \\
\text { guests }\end{array}$ & $\checkmark$ & $\checkmark$ & - & $\checkmark$ & $\checkmark$ & $\checkmark$ & - & $\checkmark$ \\
\hline Living room & receive guests & - & - & - & - & - & - & - & - \\
\hline Family room & $\begin{array}{l}\text { Watch tv/family } \\
\text { gathering }\end{array}$ & $\checkmark$ & $\checkmark$ & $\checkmark$ & $\checkmark$ & $\checkmark$ & $\checkmark$ & $\checkmark$ & $\checkmark$ \\
\hline $\begin{array}{l}\text { Main } \\
\text { bedroom }\end{array}$ & Rest/sleep & - & $\checkmark$ & $\checkmark$ & $\checkmark$ & $\checkmark$ & $\checkmark$ & $\checkmark$ & $\checkmark$ \\
\hline Bedroom & Rest/sleep & - & $\checkmark$ & $\checkmark$ & $\checkmark$ & $\checkmark$ & $\checkmark$ & $\checkmark$ & $\checkmark$ \\
\hline Kitchen & $\begin{array}{l}\text { Cooking/washing } \\
\text { dishes }\end{array}$ & $\checkmark$ & $\checkmark$ & $\checkmark$ & $\checkmark$ & $\checkmark$ & $\checkmark$ & $\checkmark$ & $\checkmark$ \\
\hline Terrace & $\begin{array}{l}\text { Sit back relax/ } \\
\text { receive temporary } \\
\text { guests }\end{array}$ & $\checkmark$ & $\checkmark$ & $\checkmark$ & - & $\checkmark$ & $\checkmark$ & $\checkmark$ & - \\
\hline
\end{tabular}

Source: Analysis Result

\section{Discussion}

From the analysis has done, researchers take some activity/activity the inhabitants of the house who attention, here, as a the:

1. The house is at 1 a common wall between the building owners, and hopefully, the contest between neighbors can be clearly heard and if any noises households an example of this was destructive acoustic comfort for another neighbor

2. Some are chosen to cover the front of the house from neighbors with a trellis on the side of the iron, right side, and sides left because they felt safe and protected. This condition is certainly was a disservice to maximize circulating air into the house and social activities certainly cannot be done 
3. Behavior occupants in almost all of the this are drying clothes in front of a house that can undermine visual while in the backyard there is a service that can be used for the activity of drying clothes

4. In the living room, although activity during pandemics never used the room within for the compulsory like some community members that have become a culture in the way of a guest at a given moment as in celebration of the large and so on

5. Of the behavior and the event, researchers trying to hold the redesigning in occupancy this to apply remedies in the occupants and the elements thermal comfort to house more comfortable. The design described in figure 12.

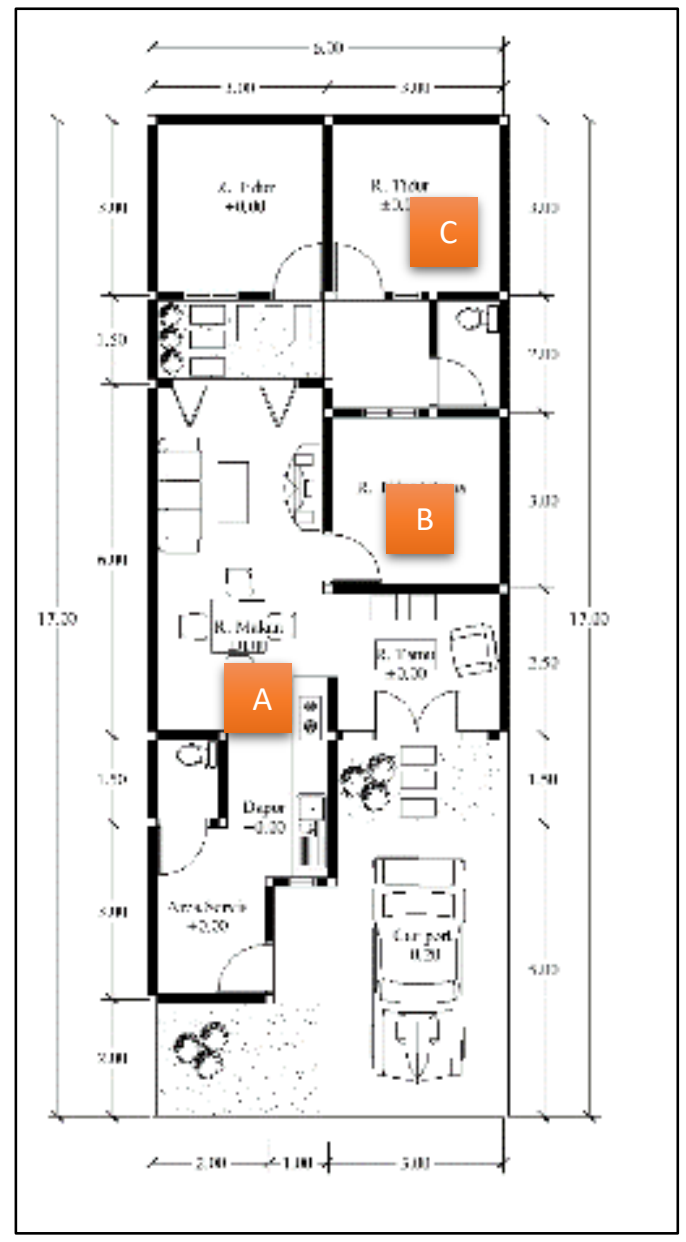

Figure 12. The redesigning floor-plan house type 70 Source: Personal Data

The type of information in floor-plain 70 after redesigning is as follows:

A. The activity of drying in front of a house can still be done because the inhabitants of the house feel that the front of the house has maximum sunlight, and the service in the future 
can also be used as an isolations entrance area, so before entering into space or privacy of public, dwellers to purify themselves and spreading viruses can be avoided.

B. The area the living room that is retained to the concept to the unique and does not deal directly with the living room.

C. There are some mini garden as area 3 bedroom so that circulating air will remain to receive circulating air and lighting

The result of the new spaces as an alternative in designing dwelling with good air circulation illustrated in figure $3 \mathrm{~d}$ here. Design explained that in figure 13.

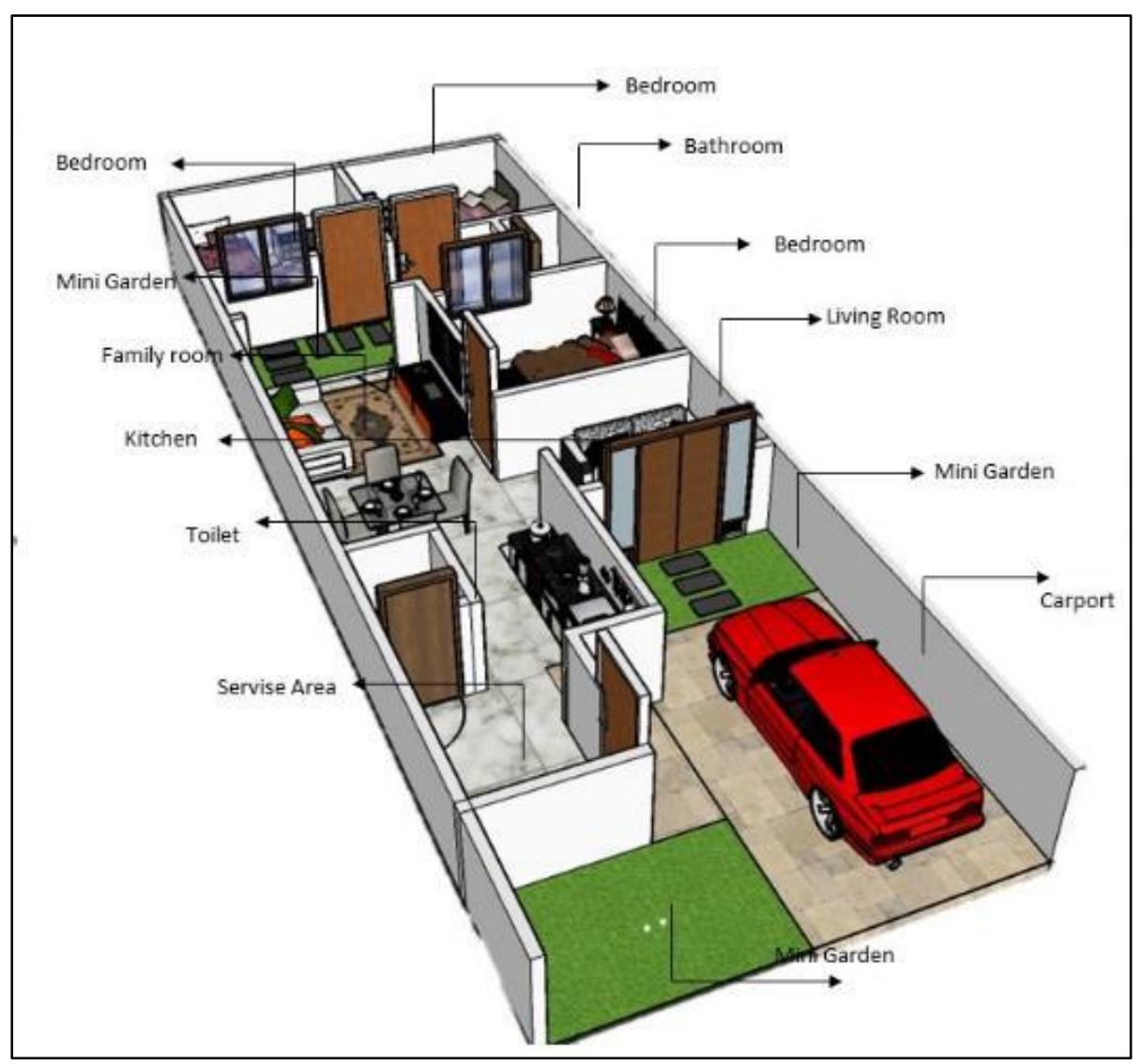

Figure 13. 3d redesigning floor-plan house type 70

Source: Personal Data

From the research, of behavior building users who love to dry the clothes in front of a house, so its design alternative is to put a service area in front of the house that can be functioned as a place of isolation before entering or went into the house of. The house space mud, design a park also placed in some parts of the house as an alternative to a sea of green as an absorbent of air pollution and created the area that pleasing by various plants. This alternative to the design of spaces remained the same as rooms on a design previously it is just that they are too adapted to the layout of residents of, where the living room since it is Indonesian culture receives guests at certain times such as a big day. The celebration of and other. In the hope of this design was becomes an 
alternative of design for the developers, a contractor and architects can build housing in the face of pandemics

\section{Conclusions}

Gave alternative some architectural design to minimize the spreading viruses and the room space as an alternative activity that is home design needs the implementation of a room like a study with good personal the back, room for activists sports, hobbies, and others. Besides design also the room for technology objects as smart, lighting the without touch, a tap without touch and others. If a few mansions can be designed desire to have as easily use architect design, but not to the majority of the community they need for dwelling and the ownership very hard, on the status as homeownership the following recorded in Medan City 55,2 percent have their own house. Therefore needs wherein the construction building front independent, which of a house to make energy own, water yourself can also use as work, having in the garden and plants to balance mental health. In the hope of this design becomes an alternative design for the developer, architect in a contractor, and to build a housing pandemic.

\section{$5 \quad$ Acknowledgment}

A thank you presented to research institutes and devotion (lppm) unimed community research program and devotion from non-tax sources in 2020, who are supporting this study run well. Education and support from the university engineering faculty building techniques in the field. To the residential neighborhood villa nusa sempurna would give Medan City researchers the required information.

\section{REFERENCES}

[1] Agustin, D., Anggriani, N., \& Djuni, E, "Influence to the spatial behavior in housing type $21 \mathrm{~m}$," in National seminar applied technologies based local knowledge (SNT2BKL), pp. 189-198. 2018.

[2] Aribowo, A. D, "The study of methods of adaptive behavior through a case study in Housing Kalijati Beautiful Bandung”, A journal itenas Rekarupa ISSN: 20088-5121, vol.5, no.2, pp. 62-70. 2019.

[3] Aufar, A. F., \& Raharjo, S. T, "Relaxation activities as coping covid-19 stress in the pandemic," A journal collaboration conflict resolution, vol.2, no.2, pp. 157. 2020. https://doi.org/10.24198/jkrk.v2i2.29126

[4] Cook, A. S, “Space and Culture. New Literary History,” vol. 29, no.3,pp. 551-572. 1989. https://doi.org/10.1353/nlh.1998.0027

[5] Imran, M., \& As'adiyah, R. B, "Design a healthy living and responsive to covid-19". in Proceeding hardiknas national seminar, pp. 1, 5-16, 2020. 
[6] Ministry of Health of the Republic of Indonesia, The prevention and control the disease coronavirus (COVID-19). Germas 2020.

[7] Education And Culture Ministry of The Republic Indonesia, Notification Letter of Republic Indonesia No Education And Culture, 2020. Number: 35952/MPK.A/HK/2020. Mendikbud RI.

[8] Khalkhali, R, "Tracing the influence of spatial behavior in the residential real estate ( case study: housing sector v bintaro jaya)". A Journal Nalars, vo.3, pp.78-95. 2004. https://arsumj.files.wordpress.com/2012/07/neoridwan.pdf

[9] Muis, A. R. C, "Transparency public policy as national strategy in reducing covid-19 pandemic". In SALAM: Islamic social and cultural journal, vol. 7, no.5.2020. https://doi.org/10.15408/sjsbs.v7i5.15317

[10] Mungkasa, O, "Work from home ( working from home / wfh ): to new order the pandemic covid 19”, A Journal development planning: The Indonesian Journal of Development Planning, vol. 4, no.2, pp. 126-150. 2020. https://doi.org/10.36574/jpp.v4i2.119

[11] Saputro, B. W., Musyawaroh, \& Handayani, K. N, "Design behavior in the architecture design market surakarta panggungrejo redesigning was good".A journal of Senthong, vol.1, no.2, pp.203-212.2018.

[12] The law of the republic of indonesia no 12011 about housing and. Settlement of the republic of Indonesia. UU No.1. 2011. 